Fall 2014

\title{
Reconnecting the Financial Sector to the Real Economy: A Plan for Action
}

Edward J. Waitzer

Osgoode Hall Law School of York University, ewaitzer@osgoode.yorku.ca

Douglas Sarro

Source Publication:

Rotman International Journal of Pension Management. Volume 7, No. 2 (2014), p. 28-36.

Follow this and additional works at: https://digitalcommons.osgoode.yorku.ca/scholarly_works

Part of the Law Commons

(c) (1) $(9)$

This work is licensed under a Creative Commons Attribution-Noncommercial-No Derivative Works 4.0 License.

\section{Recommended Citation}

Waitzer, Edward J., and Douglas Sarro. "Reconnecting the Financial Sector to the Real Economy: A Plan for Action." Rotman International Journal of Pension Management 7.2 (2014): 28-36.

This Article is brought to you for free and open access by the Faculty Scholarship at Osgoode Digital Commons. It has been accepted for inclusion in Articles \& Book Chapters by an authorized administrator of Osgoode Digital Commons. 


\title{
Reconnecting the Financial Sector to the Real Economy: A Plan for Action
}

\author{
Edward J. Waitzer and Douglas Sarro
}

Edward J. Waitzer is Professor and Jarislowsky Dimma

Mooney Chair in Corporate Governance, Osgoode Hall Law School and Schulich School of Business, York University, and Senior Partner at Stikeman Elliott LLP, Toronto (Canada).

Douglas Sarro is Associate, Sullivan \& Cromwell LLP, New York (United States).

\begin{abstract}
Informational asymmetries, misaligned incentives, and artificially elongated chains of intermediation have created a disconnect between the financial sector and the real economy that is detrimental to the public interest. Courts and regulators are increasingly intervening to break the cycle. Fiduciary law offers a conceptual framework both for understanding and responding to this trend. This article argues that the financial sector, rather than waiting for this trend to develop and reacting to new rules in a piecemeal way, should be proactive and shape the way in which the trend develops.
\end{abstract}

Keywords: Collaboration Strategies, Fiduciary Law, Financial Sector Reform, Pension Fund, Social Utility

\section{Legal Activism on the Rise}

Western society faces increasingly complex governance challenges. ${ }^{1}$ Despite growing recognition that we need to take and act on a longer-term view, the incentives for myopic leadership and action remain strong. Our willingness to control activities that have negative externalities has been limited by uncertainty about future costs and, more importantly, by a lack of incentives to price and allocate such costs equitably.

There is little question as to the trajectory of the law: by choice, by chance, or by default, it is increasingly responding to "reasonable expectations." To the extent that legislators are unable or unwilling to do so, our courts and other adjudicative tribunals have demonstrated a willingness to step in.

The regulation of corporate conduct offers a case in point. A series of decisions by courts and regulators released in recent years have held parent companies responsible for the liabilities and misconduct of their subsidiaries, notwithstanding the general principle that shareholders are not responsible for the liabilities of corporations. ${ }^{2}$ In these cases, the public interest in discouraging excessive risk taking and other harmful conduct was found to outweigh the benefits of protecting shareholders from liability.

This article focuses on similar trends in the financial sector, a sector that is critical to ensuring future well-being but in which increasing complexity in financial flows, instruments, and regulation has exacerbated informational asymmetries, eroded institutional cultures, and confounded traditional regulatory frameworks, often to the detriment of consumers and of society in general (see Hu 2012; Sah, Loewenstein, and Cain 2013; Haldane and Madouros 2012; see also Zingales 2012). We begin by providing several recent reference points, designed to illustrate the trajectory of the law and the increasing velocity and intensity of regulatory reform.

\section{A Likely Inflection Point}

Several recent examples of institutional dysfunction, and the consequent regulatory responses, suggest that we have likely reached an inflection point. In none of these examples are the highest echelons of these institutions clearly implicated in any wrongdoing, and the behavior involved may not even have been technically illegal. The problem was that these institutions focused on doing things "right," on technical compliance with whatever legal rules existed at the time, rather than on doing the right thing; as a result, they engaged in conduct that was technically legal but unfair to market participants. We argue that regulatory responses to this conduct - increasingly punitive sanctions, justified on the basis of fairness - should lead institutions to rethink their assumptions about the purpose the financial sector is intended to serve and about how best to respond to the norm of reasonable public expectations. 
Here are six examples:

1. Foreign exchange market manipulation: Regulators in several jurisdictions are investigating alleged manipulation of the US\$5.3-trillion-per-day foreign exchange market. The allegations involve collusion among traders to fix benchmark exchange rates in their favor, resulting in higher costs for consumers. In a market this large, even a scheme that skims fractional amounts translates into billions of dollars. The fact that traders' bonuses are based on trading profits gives them reason to collude, especially in the absence of transparent markets or strong oversight.

2. Mortgage misrepresentation: Since 2009, the largest American banks ${ }^{3}$ have paid out or set aside more than US $\$ 45$ billion for mortgage misrepresentation issues and have incurred roughly US $\$ 50$ billion in combined legal expenses (S\&P 2013, 2). Standard \& Poor's estimates that between US $\$ 55$ billion and US $\$ 105$ billion may have to be paid out to settle mortgage-related issues (S\&P 2013, 2). In 2013 alone, JP Morgan paid out regulatory penalties of US $\$ 20$ billion on matters ranging from mortgage misrepresentations to failing to report Bernard Madoff's suspicious activities to the authorities. Many believe that this institution, and others like it, have become so large and complex that it may be impossible to keep employees in line. According to one analyst, "there is too much of an incentive for an individual to cut corners" (Eavis 2014, quoting Paul Miller, a bank analyst at FBR Capital Markets).

3. High-frequency trading, including the early release of market information to high-frequency traders, is another area where we can expect new rules to emerge. In July 2013, Thomson Reuters suspended the practice of selling marketmoving data to high-frequency algorithmic traders up to 2 seconds ahead of making it available to other subscribers. This was in response to an investigation launched by the New York State Attorney General's office based on a whistleblower complaint. There was no allegation of conventional illegality; indeed, Thomson Reuters insisted that it had the right to "legally distribute non-governmental data" to "fee-paying subscribers" (Taibbi 2013). ${ }^{4}$

4. Other unfair informational advantage practices: BlackRock, the world's largest asset management company, recently entered into a settlement with the New York Attorney General to end its practice of surveying Wall Street analysts before public dissemination of their research reports. The firm also paid US $\$ 400,000$ to cover investigation costs. In a January 2014 press release, Attorney General Eric T. Schneiderman called BlackRock's decision to end this practice "a major step forward in restoring fairness in our financial markets and ensuring a level playing field for all investors." 5

5. Disregarding professional standards: The UK Financial Reporting Council (FRC) recently invoked new sanction powers to issue a "severe reprimand" and a $£ 14$ million fine against Deloitte for "placing their own interests ahead of the public" and compromising their own objectivity "in flagrant disregard of the professional standards expected and required" (FRC v Deloitte and Einollahi (2013), paras. 200, 270). ${ }^{6}$ The case arose out of corporate finance advice provided by Deloitte on the sale of MG Rover. While the ethics rules of the United Kingdom's professional accounting body require accountants to consider the public interest, the traditional view was that this applied only with respect to audit mandates (ICAEW 2013, paras. 1.2, 100.1; see also Irvine 2013). The tribunal explicitly rejected the notion that in corporate finance and tax work, the firm's only duty is to its client (Deloitte 2013, para. 42).

6. Failure to control investor costs: The United Kingdom's Office of Fair Trading (OFT) raised concerns about several older defined contribution (DC) plans, in which as many as 190,000 savers were thought to be paying $1 \%$ or more in annual charges (as opposed to the "new wave" of DC plans, in which charges tend to be half that amount) (OFT 2013, paras. 6.42-6.51, 9.58; see also Columbo 2013). ${ }^{7}$ The study also highlighted the lack of trustee competence and poor governance in 3,000 smaller pension schemes (OFT 2013, para. 9.25). In response to the study, the Association of British Insurers (ABI) immediately agreed to conduct an audit of the older plans (OFT 2013, para. 9.22; ABI 2013).

These examples make clear that "doing it right" is no longer enough. Regulators, courts, and legislators that find fairness problems in financial markets will intervene, often with punitive sanctions. The question is whether there is a way of understanding this pattern, predicting its future course, and prescribing conduct that avoids further sanctions. Fiduciary law offers an answer to these questions.

\section{Evolving Fiduciary Standards in the Financial Sector}

In an increasingly complex world, individuals need to trust that the specialists they retain will keep their best interests at heart (Frankel 1983). Fiduciary law aims to promote this trust (Flannigan 1989, 310; Mitchell 1997, 480). It applies to relationships in which one party gains discretionary power over another in circumstances under which both parties would "reasonably expect" that the fiduciary will exercise power in the best interests of the beneficiary. ${ }^{8}$ Fiduciary law imposes a standard of conduct higher than that normally found in the marketplace by subjecting the fiduciary to well-established duties of loyalty, obedience, and care, which, in combination, oblige the fiduciary to act prudently in the best interests of the beneficiary. 
In setting out new norms to govern the financial sector, legislators, regulators, and courts are relying on a broader view of the duty of loyalty imposed on fiduciaries, one no longer limited to disclosing or avoiding conflicts of interest. Disclosure has been shown to be, at best, an imperfect tool for managing conflicts (Cain, Loewenstein, and Moore 2005). While avoiding conflicts is a necessary step toward reinforcing trust in financial markets, it is not sufficient.

The Supreme Court of Canada's jurisprudence on the duty of loyalty offers the clearest outline of how this view works in practice. In the 2008 case BCE Inc. v. 1976 Debentureholders, the Court reviewed a claim by bondholders who alleged that the Board of BCE Inc. had not adequately considered their interests before agreeing to a change of control transaction. The Court, upholding the Board's decision, held that the Board, in executing its duty of loyalty to the corporation, was required to reflect on the interests of the corporation both as an economic actor and as a "good corporate citizen" (BCE, para. 66). The Court added that, in doing so, directors could legitimately consider not only the interests of shareholders and creditors but also broader social interests (BCE, para. 40).

In addition, the duty of impartiality requires fiduciaries to consider and balance the divergent interests of beneficiaries. ${ }^{9}$ Fiduciaries charged with managing and advising investment vehicles that encompass multiple generations of beneficiaries (e.g., defined benefit pension plans) must therefore consider the intergenerational implications of their decisions (or advice),${ }^{10}$ which imports the principle of intergenerational equity into the duty of loyalty. ${ }^{11}$ These obligations reflect the social purpose of fiduciary obligations and the importance of public trust and confidence to the continued vitality of these services.

In determining what is required to accomplish these goals, we can benefit from considering the definition of the duty of loyalty adopted in the American "public trust doctrine," which starts from the premise that social and economic progress depend on a common infrastructure the preservation of which for future generations is a vital public goal. While the present generation is entitled to reasonable use of these resources, any use that interferes with the rights of future generations is prohibited (Wood 2009a, 2009b). This principle lies at the heart of the definition of fiduciary duty, which is to preserve assets entrusted to the fiduciary. If one thinks of asset preservation as protection from inflation, it is but a small step to take a more systemic view - including protection from a degenerating environment or society.

The same logic is readily applied to the financial sector. Economic actors rely on a common infrastructure; their economic success is predicated on, among other things, equitable access to capital markets, adherence to sound governance principles; a natural environment capable of sustaining their operations; an education system that prepares the potential labour base for the workforce; and a stable, equitable economy capable of sustaining a strong consumer base for their products or services. If this infrastructure is allowed to fail, the resulting losses will be passed on to investors, both present and future. Thus, the duty of loyalty, as it is increasingly envisioned by courts, regulators, and legislators, imposes a similar resulting obligation on financial actors to preserve and continue to develop this infrastructure, as well as their own, for the public good.

\section{Five Proactive Initiatives}

In what follows we set out five initiatives that financial institutions could undertake to take into account these expectations and responsibilities, and discuss ways in which regulators and legislators can encourage institutions to embrace them. All reflect a call for a shift in emphasis from reactive regulatory and compliance strategies to proactive ones. Rather than following "check-box" compliance to regulation, institutions should anticipate future risks and consider how best to respond to them. Regulators, in turn, should shift from a strategy of imposing detailed, complex rules in response to past failures to strategies that compel institutions to think about and mitigate emerging long-term and systemic risks.

1. Rethink fiduciary duties. The fiduciary of the future will recognize and follow through on responsibilities to preserve and support the institutional system in which the fiduciary is embedded, including a duty to ensure that externalities are properly priced and moral failures are addressed (Henderson and Ramanna 2013). This will require a shift away from the zero-sum perspective that for a financial institution to "win," the client must "lose," and toward a fiduciary culture with a clearly articulated and generally accepted public purpose. ${ }^{12}$ The ten "Investment Beliefs" adopted by CalPERS (2013) offer an example of how behavioral standards reflecting such a fiduciary culture can be expressed in a pension fund context; similar standards should be adopted throughout the financial sector. Enforcement of these standards should take the form of rewards, the most powerful being advancement in the organization. If pay for performance is retained as an incentive, it should be oriented toward long-term performance and explicitly engineered to reward stewardship and a commitment to sustainability.

2. Foster "win/win" collaborations. A "trust dilemma" is a situation in which the short-term benefits of not acting until someone else steps up outweigh the short-term benefits of being the first to take action (Gilson and Gordon 2013). The way out of such a dilemma is for multiple parties to agree to share the costs. Such collaborations drive more efficient and resilient use of resources. Existing investor coalitions 
such as the International Corporate Governance Network, the United States-based Council of Institutional Investors, and the Canadian Coalition for Good Governance have produced thoughtful proposals for governance reforms and used their collective suasion to effect meaningful changes in regulation and behavior. Even more can be done through collaboration between investment intermediaries and the corporations they invest in.

3. Create legal mechanisms to protect future generations. The short-termism problem extends into our political systems (Oxford Martin Commission 2013, 45-47). One idea to counter short-termism in politics is to establish a commissioner or ombud for future generations; several countries have experimented with this idea (Weiss 2010, 110-11), which could draw on similar mechanisms for environmental and human rights that are well developed in many jurisdictions. ${ }^{13}$ Such an initiative could be supplemented by broader reforms that seek to minimize the influence of short-term political interests on government planning and priorities. More day-to-day decision making could be delegated to non-partisan independent agencies (Oxford Martin Commission 2013, 58). Guaranteed term lengths for senior administrators offer another means of securing independence from short-term political pressure (Oxford Martin Commission 2013, 58).

4. Rethink regulation. Much post-2008 financial regulation has led to complicated rules breeding complicated systems, which in turn lead to "Is it legal?" approaches that can continue to put consumers at risk. The answer may be to switch to coherent, concise, responsive, and enforceable rule making that focuses on core expectations ${ }^{14}$ Courts will also fill gaps in redefining the roles and responsibilities of fiduciaries. Models for "soft law," consensual norms that reflect "reasonable expectations" migrating into enforceable legal standards, are rapidly evolving. The UN Guiding Principles on Business and Human Rights (UNHCHR 2011) and the OECD Guidelines for Multinational Enterprises (OECD 2011) are notable examples (see Mokhiber 2013; see also Marotta 2013). Similar initiatives are being launched to develop consensual norms for sustainable financial systems. ${ }^{15}$ "Prophylactic rules" are another set of legal mechanisms that merit consideration. Like insurance, they are a means to respond to risks which, while uncertain or seemingly remote, are too significant to ignore. Such rules keep essential systems functioning while regulators determine whether a more nuanced solution ought to be imposed (Ford 2010, 298-99). Regulators should have both the legal power and the confidence to impose these kinds of mechanisms before they have complete certainty as to the nuances of the problem.

5. Reassert the social utility of the financial sector. Current public perceptions of this sector are dominated by lack of understanding and lack of trust (Bowman and Rugg 2013).
While continuing to enjoy heavy public subsidies, ${ }^{16}$ the financial sector is perceived to have massively misallocated capital and generated suboptimal social returns. A major campaign is needed to better explain the products, services, and markets that help mobilize capital and price or allocate risk in a well-functioning economy. This work is already underway, but should be accelerated (Sandor et al. 2014; Chong and Kleemann 2011). Likewise, regulators and policy makers for the financial sector should convey that financial regulation is not just about protecting consumers from deceptive products and practices but also about ensuring that society is well served by the financial sector so that consumers get a "fair deal." Public stewardship responsibilities should be clearly articulated throughout the financial services supply chain. ${ }^{17}$

We believe that implementing these five initiatives, taken together, would materially raise the perception and reality of the financial sector's social utility around the world.

\section{Doing the Right Thing}

The trajectory of the law is clear: regulators, legislators, and courts are expanding fiduciary duties based on reasonable expectations that the financial sector should serve the public interest.

The financial sector has a choice: it can continue to be reactive, and seek to maintain an unsustainable status quo, or it can take a proactive and collaborative approach that responds to this rapidly emerging dynamic. The immediate consequences of choosing the first option are already well known: more regulation with higher compliance (and forgone opportunity) costs, higher penalties, lower public confidence, and a less effective financial system. The longer-term consequences, environmental and social as well as financial, of a failure to be proactive pose greater threats (WEF 2014, 23).

In his first economic message, Pope Francis noted that "whatever is fragile, like the environment, is defenseless" against markets that show a "lack of real concern for human beings" (2013, paras. 55-56). He argued that a financial system imbued with ethical values "would make it possible to bring about balance and a more human social order" (2013, para. 57). The Pope's remarks reflect a broader current in public opinion, a current that is increasingly reflected in the actions of regulators and courts: the understanding that the market system has achieved tremendous successes, and continues to have enormous potential to serve the common good, but that this potential can be achieved only if the financial sector is guided by a sense of social purpose. This is the inflection point that our financial sector will either embrace or have imposed upon it. 


\section{Endnotes}

1 This article draws from "Fiduciary Society Unleashed: The Road Ahead for the Financial Sector," The Business Lawyer 69 (4), forthcoming in 2014. We thank Keith Ambachtsheer, Jean Frijns, Jack Gray, Larry Hamermesh, Steve Lydenberg, and Allen Willis for their helpful comments.

2 See, e.g., PBGC v Asahi Tec Corp (2013), in which the US District Court for the District of Columbia concluded that a Japanese corporation could be held liable for the underfunded pension liabilities of its bankrupt American subsidiary, despite the corporation's argument that the court lacked jurisdiction; and Choc v Hudbay Minerals (2013), in which the Ontario Superior Court denied a motion by Hudbay Minerals Inc. to dismiss a claim arising from security incidents at a mine operated by its Guatemalan subsidiary, during which one man died, another man was seriously injured, and several women were raped.

3 Bank of America, Citigroup, Goldman Sachs, JPMorgan Chase, Morgan Stanley, and Wells Fargo.

4 More recently, Berkshire Hathaway's Business Wire reported that after consultations with the New York Attorney-General's office, it has decided to stop giving high-speed traders direct access to news releases (see Paterson 2014).

5 New York State Office of the Attorney General (2014); Morgenson (2014).

6 The FRC found that Deloitte had failed to manage conflicts of interest arising from the dual role it took on as auditor to MG Rover and advisor to a group of directors that sought to buy the company. The directors succeeded in buying the company in 2000, but it collapsed in 2005 .

7 According to the OFT report, the life-cycle effect of a $1 \%$ annual charge can reduce retirement savings by around $20 \%$.

8 Historically, fiduciary duties applied only to lawyers, partners, corporate directors, and trustees. The Supreme Court of Canada has led the commonlaw world in adopting a more principled approach to defining fiduciary duties. See Guerin v The Queen (1984); Bristol \& West Building Society v Mothew (1996); and United States v Chestman (1991). The circumstances in which a reasonable expectation that one party will act in the best interests of the other will arise vary from jurisdiction to jurisdiction, but most commonly occur where such an undertaking is imposed by statute or by agreement, or where one party seeks advice from another party on a highly specialized field (e.g., law or medicine) in which the latter party has expertise. See Galambos v Perez (2009, para. 84).

9 Restatement (Third) of Trusts: Prudent Investor Rule, §78; Edge v Pensions Ombudsman (1998).

10 See Withers v Teachers' Retirement System of City of New York (1978); Varity Corp v Howe (1996).

11 See, e.g., Bennett v British Columbia (2009); BC Nurses' Union v Municipal Pension Board of Trustees (2006).
12 The 10 Investment Beliefs adopted in fall 2013 by the California Public Employee Retirement System (CalPERS) are illustrative, in that they reflect an understanding of the relationship between wealth generation, sound institutions, and a sustainable environment. For instance, Belief 2 states that "[a] long term investment horizon is a responsibility and an advantage." In light of this belief, CalPERS pledges to "consider the impact of its actions on future generations of members and taxpayers," "favor investment strategies that create long-term sustainable value," and "advocate for public policies that promote fair, orderly and effectively regulated capital markets." Belief 9 concedes that "risk to CalPERS is multi-faceted and not fully captured through measures such as volatility or tracking error." To address this, CalPERS commits to "consider risk factors, for example climate change and natural resource availability, that emerge slowly over long time periods, but could have a material impact on company or portfolio returns" (CalPERS 2013).

13 One example of such a mechanism is the United Kingdom's Sustainable Development Commission, an independent watchdog charged with monitoring and reporting on the government's progress in implementing its sustainable development strategy.

14 For example, the US Federal Reserve recently issued a statement of bank capital planning that stipulated the need for "economically intuitive" criteria by which directors and management are to judge actions throughout a firm and for which they will be held accountable (Federal Reserve Board 2013, 18). Another key is to focus on emerging risks, particularly for those most vulnerable, rather than simply responding to past failures. The US Office of Financial Research, established under the Dodd-Frank Act to "to improve the quality of financial data available to policymakers and to facilitate more robust and sophisticated analysis of the financial system" (OFR 2013), may prove a useful mechanism for promoting a more holistic, forward looking and effective regulatory paradigm. This is a key argument for integrated reporting - promoting a more holistic view of value creation.

15 For example, the United Nations Environment Programme (UNEP) launched such an inquiry in January 2014, aiming to identify and link a growing number of complementary initiatives in "green" and sustainable finance. In the same month, the Chinese Development Research Center of the State Council launched a public inquiry on "Greening China's Financial System" (UNEP 2014). The leadership of emerging nations in this area is particularly promising.

16 These subsidies come in a variety of forms, including access to subsidized funding and regulatory entry barriers. According to one recent study, for the 10 largest American banks, "too big to fail" status alone means benefits equivalent to an annual subsidy of US\$83 billion from taxpayers (see "Why Should Taxpayers" 2013).

17 This concept is already being mooted by regulators. For example, US Federal Reserve Governor Daniel K. Tarullo recently made a compelling argument for modifying the fiduciary duties of bank directors to include bank regulatory objectives (Tarullo 2014). 


\section{References}

Association of British Insurers [ABI]. 2013. "A New Retirement - Call for Evidence."

https://www.abi.org.uk/Insurance-and-savings/Topics-and-issues/A-new-retirement/Call-for-evidence

BCE Inc v 1976 Debentureholders, 2008 SCC 69, [2008] 3 S.C.R. 560

BC Nurses' Union v Municipal Pension Board of Trustees, 2006 BCSC 132, 50 CCPB 77.

Bennett v British Columbia, 2009 BCSC 1358, 77 CCPB 56

Bowman, Karlyn, and Andrew Rugg. 2013. "Five Years after the Crash: What Americans Think about Wall Street, Banks, Business, and Free Enterprise." American Enterprise Institute Political Report, September 10.

http://www.aei.org/book/politics-and-public-opinion/polls/five-years-after-the-crash-what-americans-think-about-wall-street-banks-business-and-free-enterprise/

Bristol \& West Building Society v Mothew, [1996] 4 All ER 698 (CA)

Cain, Daylian M., George Loewenstein, and Don A. Moore. 2005. "The Dirt on Coming Clean: Perverse Effects of Disclosing Conflicts of Interest."

Journal of Legal Studies 34 (1): 1-25. http://dx.doi.org/10.1086/426699

CalPERS. 2013. "CalPERS Investment Beliefs." http://www.calpers.ca.gov/eip-docs/about/pubs/board-offsite.pdf.

Choc v Hudbay Minerals Inc, 2013 ONSC 1414, 116 OR (3d) 674.

Chong, Paul, and Linda Kleemann. 2011. "The Future of Funding for Social Enterprises.” Global Economic Symposium 2011.

http://www.global-economic-symposium.org.

Columbo, Josephine. 2013. “OFT stops short of a fees cap.” Financial Times (September 20), 3.

Eavis, Peter. 2014. "Steep Penalties Taken in Stride by JPMorgan.” New York Times (January 8), A1.

Edge v Pensions Ombudsman, [1998] Ch 512, aff'd [1999] EWCA Civ 2013, 4 All ER 546 (CA).

Federal Reserve Board. 2013. "Capital Planning at Large Bank Holding Companies: Supervisory Expectations and Range of Current Practice." http://www.federalreserve.gov/bankinforeg/bcreg20130819a1.pdf

Flannigan, Robert. 1989. “The Fiduciary Obligation.” Oxford Journal of Legal Studies 9 (3): 285-322. http://dx.doi.org/10.1093/ojls/9.3.285

Ford, Cristie L. 2010. "Principles-Based Securities Regulation in the Wake of the Global Financial Crisis." McGill Law Journal 55 (2): $257-307$. http://dx.doi.org/10.7202/045086ar

Pope Francis. 2013. Evangelii Gaudium. Vatican City: Vatican Press.

Frankel, Tamar. 1983. "Fiduciary Law.” California Law Review 71 (3): 795-836. http://dx.doi.org/10.2307/3480303.

FRC v Deloitte and Einollahi. 2013. Report of the Tribunal, Financial Reporting Council. http://goo.gl/SDjTLM

Galambos v Perez, 2009 SCC 48, [2009] 3 SCR 247.

Gilson, Ronald J., and Jeffrey N. Gordon. 2013. "The Agency Costs of Agency Capitalism: Activist Investors and the Revaluation of Governance Rights." Columbia Law Review 113 (4):863-928.

Guerin v. The Queen, [1984] 2 SCR 335.

Haldane, Andrew G., and Vasileios Madouros. 2012. "The Dog and the Frisbee.” Given at the Federal Reserve Bank of Kansas City's 36th economic policy symposium, "The Changing Policy Landscape, Jackson Hole, Wyoming, August 31, 2012.

Henderson, Rebecca, and Karthik Ramanna. 2013. "Managers and Market Capitalism.” Harvard Business School Working Paper No. 13-075.

Hu, Henry T.C. 2012. “Too Complex to Depict? Innovation, 'Pure Information,' and the SEC Disclosure Paradigm.” Texas Law Review 90 (7):1601-715.

Institute of Chartered Accountants in England and Wales (ICAEW). 2013. "Code of Ethics."

http://www.icaew.com/en/technical/ethics/icaew-code-of-ethics. 


\section{References (cont'd)}

Irvine, Julia. 2013. "Unintended Consequences of MG Rover.” economia, September 13.

http://economia.icaew.com/opinion/september-2013/unintended-consequences-of-mg

Marotta, Francesca. 2013. Letter from Francesca Marotta, Officer-in-Charge, Development and Economic and Social Issues Branch, Officer of the High Commissioner for Human Rights, to Roel Nieuwenkamp, Chair, Working Party for Responsible Business Conduct, Organization for Economic Cooperation and Development, November 27. http://www.ohchr.org/Documents/Issues/Business/LetterOECD.pdf

Mitchell, Lawrence E. 1997. “The Naked Emperor: A Corporate Lawyer Looks at RUPA’s Fiduciary Provisions.” Washington and Lee Law Review 54 (2): $465-86$.

Mokhiber, Craig. 2013. Letter from Craig Mokhiber, Chief, Development and Economic and Social Issues Branch, Officer of the High Commissioner for Human Rights, to Joris Oldenziel, Centre for Research on Multinational Corporations, April 26. http://www.ohchr.org/Documents/Issues/Business/LetterSOMO.pdf

Morgenson, Gretchen. 2014. “BlackRock Agrees to Stop Pursuing Nonpublic Views.” New York Times, January 9, B1.

New York State Office of the Attorney General. 2014. "A.G. Schneiderman Announces Agreement with BlackRock to End Its Analyst Survey Program Worldwide.” Press release, January 9. http://www.ag.ny.gov/press-release/ag-schneiderman-announces-agreement-blackrock-end-its-analyst-survey-program-worldwide

OECD. 2011. "Guidelines for Multinational Enterprises." http://www.oecd.org/daf/inv/mne/48004323.pdf

Office of Fair Trading. 2013. "Defined Contribution Workplace Pension Market Study."

http://webarchive.nationalarchives.gov.uk/20131101164215/http://www.oft.gov.uk/shared_oft/market-studies/oft1505

Office of Financial Research. 2013. "About the OFR.” http://www.treasury.gov/initiatives/ofr/about/Pages/default.aspx

Oxford Martin Commission for Future Generations. 2013. "Now for the Long-Term: The Report of the Oxford Martin Commission for Future Generations." http://www.oxfordmartin.ox.ac.uk/downloads/commission/Oxford_Martin_Now_for_the_Long_Term.pdf.

Paterson, Scott. 2014. “Traders’ Access to Releases Curbed.” Wall Street Journal (February 21), C1. http://online.wsj.com/news/articles/SB20001424052702303775504579395294278799538

PBGC v Asahi Tec Corp, No. 10-1936 (ABJ), 2013 WL 5503191 (DDC Oct 4, 2013)

Restatement (Third) of Trusts: Prudent Investor Rule. 1992. American Law Institute.

Sah, Sunita, George Loewenstein, and Daylian M. Cain. 2013. "The burden of disclosure: Increased compliance with distrusted advice." Journal of Personality and Social Psychology 104 (2): 289-304. http://dx.doi.org/10.1037/a0030527.

Sandor, Richard L., Nathan Clark, Marali Kanakasabi, and Rafael L. Marques. 2014. "Environmental Markets: A New Asset Class.” CFA Institute, January.

Standard \& Poor's Ratings Services [S\&P]. 2013. "The Largest U.S. Banks Should Be Able to Withstand the Ramifications of Legal Issues".

Taibbi, Matt. 2013. "Sixteen Major Firms May Have Received Early Data from Thomson Reuters.” Rolling Stone (September 5). http://www.rollingstone.com/politics/blogs/taibblog/16-major-firms-may-have-received-early-data-from-thomson-reuters-20130905

Tarullo, Daniel. 2014. Remarks at the Midyear Meeting of the Association of American Law Schools: Corporate Governance and Prudential Regulation, June 9. http://www.federalreserve.gov/newsevents/speech/tarullo20140609a.pdf.

United Nations Economic Programme [UNEP]. 2014. "Inquiry into the Design of a Sustainable Financial System: Policy Innovations for a Green Economy." http://www.unep.org/greeneconomy/financialinquiry/.

United Nations High Commissioner for Human Rights [UNHCHR]. 2011. "Guiding Principles on Business and Human Rights.” http://www.ohchr.org/Documents/Publications/GuidingPrinciplesBusinessHR_EN.pdf

United States v Chestman, 947 F2d 551 (2d Cir 1991).

Varity Corp v Howe, 516 US 489 (1996).

Weiss, Edith Brown. 2010. “Implementing Intergenerational Equity.” In Research Handbook on International Environmental Law, ed. Malgosia Fitzmaurice, David M. Ong, and Panos Merkouris, 100-116. Northampton, MA: Edward Elgar. http://dx.doi.org/10.4337/9781849807265.00013

“Why Should Taxpayers Give Big Banks 83 Billion a Year?” 2013. Bloomberg, February 20.

http://www.bloomberg.com/news/2013-02-20/why-should-taxpayers-give-big-banks-83-billion-a-year-.html 


\section{References (cont'd)}

Withers v Teachers' Retirement System of City of New York, 447 F Supp 1248 (SDNY 1978).

Wood, Mary Christina. 2009a. "Advancing the Sovereign Trust of Government to Safeguard the Environment for Present and Future Generations (Part I): Ecological Realism and the Need for a Paradigm Shift.” Environmental Law 39:43-89.

Wood, Mary Christina. 2009b. “Advancing the Sovereign Trust of Government to Safeguard the Environment for Present and Future Generations (Part II): Instilling a Fiduciary Obligation in Governance.” Environmental Law 39:91-139.

World Economic Forum. 2014. Global Risks Report 2014, 9th ed. Geneva: World Economic Forum.

Zingales, Luigi. 2012. "Why I Was Won Over by the Merits of Glass-Steagall." Financial Times (June 11), 11. 


\section{About Rotman International Centre for Pension Management}

The mission of the Rotman International Centre for Pension Management (Rotman ICPM) is to be an internationally-recognized, high-impact catalyst for fostering effective pension design and management. Its four primary tools to achieve this goal are the funding of objective and transformative research, the organization of interactive, action-oriented discussion forums, the publication of a readable journal relevant to professionals in the pensions and related fields, and the delivery of the globe's leading governance education program for Board members of pension and other longhorizon investment institutions.

\section{Editor}

Keith Ambachtsheer

\section{Associate Editor}

Ann Henhoeffer

\section{Copy Editor}

Sylvia Hunter

Design

watermarkdesign.ca

\section{i CPM}

International Centre for Pension Management

105 St. George Street Toronto, Ontario Canada M5S 3E6

Tel: 416.925 .4153

icpm@rotman.utoronto.ca www.rotman.utoronto.ca/icpm

\section{Editorial Advisory Board}

Australia

Jack Gray - Sydney University of Technology

Gordon Hagart - Australian Council of

Superannuation Investors (ASCl)

Wilson Sy - Investment Analytics

Canada

James Davis - Ontario Teachers' Pension Plan

Malcolm Hamilton - Mercer (Canada)

Patrick Savaria - Caisse de dépôt et placement du Québec

Denmark

Ole Beier Sørensen - Danish Labour

Market Supplementary Pension (ATP)

Japan

Sadayuki Horie - Nomura Research Institute

New Zealand

Tim Mitchell - New Zealand

Superannuation Fund

\section{4 / 2015 Research Partners}

\section{International}

Global Risk Institute in Financial Services

The World Bank

Australia

Australia Future Fund

Australian Super

QSuper

Queensland Investment Corporation

SunSuper

UniSuper

Canada

Alberta Investment Management Corporation

Alberta Local Authorities Pension Plan

British Columbia Investment Management

Corporation (bclMC)

Caisse de dépôt et placement du Québec

Canada Pension Plan Investment Board

Healthcare of Ontario Pension Plan

Ontario Municipal Employees Retirement System

Ontario Teachers' Pension Plan

Public Sector Pension Investment Board

Denmark

Danish Labour Market Supplementary Pension (ATP)

Pensionskassernes Administration (PKA)

Finland

Finland State Pension Fund

Ilmarinen

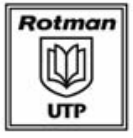

C) 2014 Rotman International Journal of Pension Management is published by Rotman International Centre for Pension Management at the Rotman School of Management, University of Toronto, CANADA in partnership

with Rotman/University Toronto Press. The views expressed are those of the authors, and do not necessarily represent those of Rotman ICPM or its Research Partners, the Rotman School of Management or the University of Toronto.

Rotman International Journal of Pension Management is distributed at no charge as an electronic journal and can be accessed by visiting www.rotman.utoronto.ca/icpm. Print copies can be purchased at a cost of $C \$ 50.00$ per issue (includes tax and shipping). To order print copies please visit www.rotman.utoronto.ca/icpm.

\section{Netherlands}

Rob Bauer - Maastricht University

Dirk Broeders - De Nederlandsche Bank

Jean Frijns - Corporate Director

Theo Kocken - Cardano

Sweden

Urban Karlström - Första AP-fonden (AP1)

United Kingdom

Gordon L. Clark - Oxford University

Roger Urwin - Towers Watson

United States

Don Ezra - Russell Investments

Brett Hammond - MSCI Barra

Stephen Lerch - State of Washington

Unsolicited articles can be submitted via PRESTO! for consideration by the Editorial Advisory Board. Please visit http://rotmanijpm.presto. utpjournals.com/jmanager/users/login

\section{France}

Etablissement de Retraite Additionelle de la Fonction Publique (ERAFP)

Japan

Nomura Research Institute

Netherlands

Algemene Pensioen Groep

MN

De Nederlandsche Bank

PGGM

New Zealand

New Zealand Superannuation Fund

Sweden

Första AP-Fonden (AP1)

United Kingdom

National Employment Savings Trust

Railways Pension Trustee Company Ltd.

Universities Superannuation Scheme

United States

California Public Employees' Retirement System California State Teachers' Retirement System

State Board of Administration of Florida (SBAFLA) TIAA-CREF

Washington State Investment Board

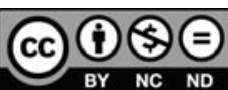

This work is licensed under the Creative Commons Attribution-NoncommercialNo Derivative Works 2.5 Canada License. Under Creative Commons, authors retain ownership of the copyright for their article, but authors allow anyone to download, reuse, reprint, distribute, and / or copy articles from the journal, as long as the original author(s) and source are cited. No permission is required from the Author(s) or the Publisher. To view a copy of this license please visit www.rotman.utoronto.ca/icpm.

ISSN 1916-9833 (Print) - C $\$ 50.00$ ISSN 1916-9841 (Online) - no charge 